Article

\title{
Perceptions of Water Pricing during a Drought: A Case Study from South Australia
}

Eileen Willis $^{1, *}$, Meryl Pearce ${ }^{2}$, Loreen Mamerow ${ }^{1}$, Bradley Jorgensen ${ }^{3}$ and John Martin ${ }^{3}$

1 School of Medicine, Flinders University, Adelaide, South Australia 5001, Australia;

E-Mail: loreen.mamerow@googlemail.com

2 School of the Environment, Flinders University, Adelaide, South Australia, 5001, Australia; E-Mail: meryl.pearce@flinders.edu.au (M.P.)

3 Centre for Sustainable Regional Communities, La Trobe University, Bendigo, Victoria 3552, Australia; E-Mail: B.Jorgensen@1atrobe.edu.au (B.J.); John.Martin@1atrobe.edu.au (J.M.)

* Author to whom correspondence should be addressed; E-Mail: eileen.willis@flinders.edu.au; Tel.: +61-8-8201-3110; Fax: +61-8-8201-3110.

Received: 7 December 2012; in revised form: 13 January 2013 / Accepted: 21 January 2013 / Published: 4 February 2013

\begin{abstract}
This paper examines the perceptions of urban and regional water consumers in three areas of South Australia on the fairness of the water pricing system, the impact of increases in water pricing on households and pricing as a driver of water conservation. The study was conducted in 2009 during a time of severe drought and mandatory water restrictions. The results did not show a general aversion to all aspects of price increases but rather different sectors of the population were particularly resistant to different, specific aspects of water pricing. A state-wide water pricing policy in South Australia means that all consumers pay the same rate per volume of water consumed regardless of their location; yet in the regional study area, where it costs more for the service provider to supply the water, the respondents had stronger feelings that the price of water should be higher in places where it costs more to supply it. Generally, low income earners were less in favor of a block pricing system than higher income earners. The latter findings indicate a common lack of awareness around various aspects of water pricing. Some implications of the findings for water managers are outlined.
\end{abstract}

Keywords: water pricing; conservation; drought; socio-economic 


\section{Introduction}

This paper examines the perceptions of residents from differing socio-economic backgrounds on the fairness of household water pricing, increases in water prices and pricing as a driver of conservation. The research questions are: How do residents with different demographic characteristics perceive (i) the fairness of water pricing (including the tariff structure); (ii) increases in water prices; and (iii) water pricing as a strategy to motivate conservation? The study took place during a period of prolonged below average rainfall and mandatory water restrictions in South Australia. The areas studied included a cluster of suburbs in the northern part of greater metropolitan Adelaide (henceforth referred to as Metro North), a cluster in the eastern metropolitan area (Metro East) and a large regional town in South Australia (Regional). The areas were chosen based on their urban or rural standing and their socio-economic characteristics.

The paper is structured as follows: Section 1 provides some contextual background to the study, through the literature review followed by the methodology. The results section opens with a summary of the demographic characteristics of the survey respondents. Based on the data analysis a number of predictor variables for aspects of water pricing were identified, these are then discussed under the socio-economic and demographic subheadings. A discussion of the key findings and the implications of the results bring the paper to a close. This includes an examination of the limitations of the study.

\subsection{Review of the Literature}

Price increases are seen as effective in reducing consumption and are presumed to lead to household water efficiencies [1,2]. Despite this, there is considerable debate around the value of regulation or market driven approaches to water conservation [3-9]. While economists generally stress the efficiency of pricing, environmentalists emphasis the effectiveness of regulation as a conservation measure. While these two approaches are not necessarily mutually exclusive, the efficiency argument stresses the use of price control as a way of reducing water consumption, while effectiveness may put the stress on water restrictions as a way to reduce consumption. However, equity is not simply a matter of cost efficiency, it may also refer to the way different socio economics groups use water as part of everyday life, and for this the effectiveness of water restrictions may be an issue.

Barrett [1] notes that there is a world-wide trend to use the market as a strategy for reducing consumption on a range of essential services, although this is not the only mechanism for reducing consumption. The market approach implies that raising prices and moving full cost recovery on to the consumer is the most efficient conservation mechanism, as the price is the major motivator to consumption reduction. In this approach there is less reliance on maintaining water reduction either through government regulation, that may be more effective, but must be monitored, or behavioral change campaigns which must be constantly renewed [1-3]. However, public opposition to increases in water pricing makes the price increase strategy difficult [10], and often data on the real costs are not available [1]. In Australia the prescription on all state governments to move to full cost recovery in line with legislation introduced in 2004 makes reducing the price of water difficult [11]. Achieving full cost recovery is also difficult given the complexities of determining the costs; economic, environmental and social, and how these costs should be defrayed. 
While there is much debate in the literature around whether pricing or water restrictions are the more effective means of driving water conservation, much of the argument rests on the negative side of the difficulties of enforcing water restrictions and other conservation measures over a sustained and long term [2]. The tensions between economic and environmentally driven policy in setting the price of water, and in policy formation has been taken up by a number of researchers concerned with issues of equity and social justice of water allocations [12-14]. With reference to water allocations, public perceptions on equity and social justice relate to the fairness of water provision for individuals, the environment, and for future generations, and less about economic-driven decisions [15]. Kanakoudis et al. [16] (p. 54) note that the social justice and equity arguments assume 'consumers must pay fair prices for water services provision'. When focusing on domestic water supply, equity and social justice refer to the rights of consumers to have fair access to reasonably priced water, although as will become clear, many consumers have little understanding of what is a fair price, or what exactly they are paying for. For example, both Alston and Mason [12] and Lockie and Rockloff [13] argue that focusing on the technical aspects of the economy or the environment in setting the price of water misses other social aspects or what they [12] refer to as social flows. In outlining their concept of social flows they argue that besides the economic and environmental components, water also has a social or cultural value, that may differ according to gender, race or class interests; for example rural irrigators concerned with food production may not have the same interests as a female suburban pensioner pottering in her garden. They suggest that this is most evident in the composition of various water governing authorities. These are invariably made up of stake holders from either the environmental or economic lobbies, and seldom include representation from those whose interest in water is cultural or social, and so their interests may not be taken into account. The concept of social flows is hence part of water economics. It goes beyond the capital outlays of water production or the costs of environmental sustainability to include opportunity costs, the aesthetic aspects of the landscape or the pleasure derived from fountains, swimming or sailing in lake $[12,17]$. Walking the line between cost recovery, conservation and affordability, along with ensuring an equitable approach to the varying interest groups is no easy task. The distinction between market, regulatory and behavioral approaches to water consumption reduction owes much to the insights of one of the reviewers of this paper.

A number of studies have documented the social or welfare costs associated with water restrictions particularly among householders with a strong interest in gardens [18,19], and a concomitant high external water use. In Australia, gardening is a popular pastime. The broader social flow and financial costs of water restrictions should thus not be underestimated. During the drought in New South Wales, some residents who did not want to breach water restrictions but had a keen interest in maintaining their garden purchased rainwater tanks for that sole purpose. In doing so they abided by the restrictions (by not using excess mains water on the garden), but the cost of purchasing a rainwater tank and installing an irrigations system connected to the rainwater solely for garden use far exceeded the price of using mains water for garden irrigation. Despite this self-incurred cost associated with using rainwater tanks, it was deemed worthy by the residents. While this behavior maintains high water using habits, which is counter to the conservation objective of restrictions, from a pricing perspective it indicates that some people prefer to maintain their garden regardless of the cost, and highlights the aesthetic or social flow value that some people place on healthy gardens [20]. 
The direct impact of price increases of essential services on lower income groups has been widely researched [1,21-24] with the argument that the price of water has a greater impact on poorer households than it does on middle and upper income households simply because a higher proportion of their income is spent on water. Despite these negative findings about price increases, Olmstead and Stavins [2] argue that price increases can impact positively on low income families by providing savings that far exceed that of other approaches. Examples include the fact that price increases allow water utilities to extend services to groups that may not be well serviced, may result in more efficient forms of consumption, reduction in demand or more efficient forms of allocation that result in higher returns [17]. It is also possible that with price increases, conservation measures become affordable alternatives, or projects that were once perceived to be marginal, are now profitable [17].

One of the strategies used with low income groups is block pricing or tiered charges. Block pricing can enable a free basic water allowance to be provided to low income households, or the first block can be set at a sufficiently low price to benefit low income households [6]. High water users then pay a premium for above average water use. In South Africa, where there are large income differentials in the population the block pricing strategy, aimed at cross-subsidization, was supported by a majority of survey respondents regardless of their income, ethnicity, and urban or rural location [25]. Similarly, an analysis of water pricing in Sao Paulo, Brazil showed that increasing-block pricing favored low income households, while a flat price favored higher income earners [26]. Others argue against increasing-block pricing based on inequity [27] and evidence to suggest that it is only marginally effective in reducing water consumption [28,29]. Although variable, linear- or increasing-block pricing is widely used in OECD countries [27]. This implies that increases in water pricing are predominantly driven by a need to lower water use rather than cost recovery. However, a problem arises in that if prices remain fixed, but consumption drops the water utility loses revenue [2]. Increasing-block water pricing designed to support low income households can also result in a loss of revenue to water utilities [26], so that increasing the price of water may be less about conservation than it is around the principle of full cost recovery. Direct costs to the service provider include those related to building, operating and maintaining infrastructure; sourcing, treating, storing and reticulating the potable supply, and ensuring that it complies with the drinking water standards.

In addition to direct costs, Kanakoudis et al. [16] state that resource and environmental costs should also be included in the price of water. Further, based on a study in water-scarce Cyprus, Zachariadis [29] emphasizes the need for water scarcity pricing to be included in the costs to consumers. Water scarcity pricing is where the price of water is raised above a threshold level during times of water shortages as a strategy to direct water to the highest value uses. While this may be seen as inequitable and orientated towards those able to afford the higher prices, such inequities can be offset by setting a threshold water use level beyond which pricing applies. Thus, low income families would not pay the elevated prices provided their water use remains below the threshold level [30]. Similarly the Official Journal of the European Union [30] (p. 13) states that 'not only should water pricing consider the social, environmental and economic costs but should also consider the geographic and climatic context of water service provision'. This is because some regions are more prone to frequent and severe water shortages and are likely to be further adversely impacted by climate change [29]. Further, climate change projections indicate marked spatial variability of impacts, with already dry regions expecting to be the most adversely impacted. Savenije and van der Zang [31] (p. 103) acknowledge the need for 
ecological requirements to be met and for fairness in providing water to low income households, but comment:

If water pricing is considered the main (sole) instrument of demand management and economic planning, it will be a major pitfall. Both demand management and economic planning should have much broader scopes, and the core function of water pricing should primarily be cost recovery.

In short, appropriate water pricing policy should lead to improved managerial efficiency, and satisfy social and equity criteria while ensuring financial and resource sustainability [30,31]. Although cost recovery was seen as the most important aspect of water pricing by Savenije and van der Zang [31], appropriately priced water should 'provide incentives for users to use water resources efficiently' [30] (p. 13).

In terms of consumer awareness around water pricing the research evidence is mixed on what residents actually know about the price they pay for water, how much water they use, or its relative cost. Research by Troy and Randolph [32] conducted in New South Wales, Australia indicated that less than $20 \%$ of residents had any idea of how much they used or paid for water. These figures differed by dwelling type, which was used as a proxy for socio-economic status, with fewer than $6 \%$ of flat dwellers aware of their water use or costs. Interestingly, 50\% thought the current water prices were fair, while $20 \%$ did not. Further to this, $93 \%$ of participants in the study believed they used the same or less water than the average household. Of those who did know how much they used, they did not believe there were seasonal differences in their water use. As a consequence, conservations efforts were limited.

An additional factor in water conservation is the type of housing, including house size. Numerous studies [32-36] have shown a correlation between high water use and a greater number of water-using outlets and the presence of swimming pools and spas, large gardens [37], lot size, and the sophistication of the garden-watering system [22-37]. In a study by Willis et al. internal household water use was predicted by income group, type of housing, types of appliances used and the number of household occupants [38]. Barberán and Arbués [27] recommend including a per capita component in block water pricing to counter the disadvantages faced by households with a greater number of occupants, but admit that it would be difficult to administer. While wealthier households (with larger houses and gardens) may have more water-using amenities (such as spas, swimming pools and a greater number of bathrooms) that are correlated with higher water use, it may be argued that they are also most able to afford water saving technologies such as sub-surface irrigation systems, garden mulch, rainwater tanks, and the ability to replace washing and dishwashing machines with water-efficient models [32-39], once again confounding our ideas of what is the most equitable policy approach.

In summary, while price increase is just one mechanism for conserving water it is not without its social and political complexity and critics [31]. As demonstrated above it may not be the most apt method of water reduction to target wealthier households and industries that can afford the higher prices and may chose to do so [22-39]. Despite this, it remains a favored approach, particularly by economists, as unlike behavioral approaches to consumption reduction favored by environmentalists, price increases are an efficient strategy for policy makers. Price increases have the advantage of being 
long term and are not dependent on monitoring or penalizing householder or industry for over use. It does not require the introduction of surveillance mechanisms where regulation is used to contain or reduce consumption, and it is more reliable and sustainable than mass conservation education campaigns that aim to alter behaviors over the long term $[1,2]$.

\section{Context}

\subsection{Drought and Water Restrictions}

This study was conducted in 2009 following a decade of above average temperatures across Australia. Most cities had water restrictions in place from early to mid-2000 and for the duration of the study [22]. Mandatory water restrictions had been in place in Adelaide since 2003, and became more restrictive as the drought progressed. The rural study area (Regional), as with many country towns, was subject to the less restrictive Permanent Water Conservation Measures (PWCM). Restrictions and PWCM mostly restricted external water consuming activities such as washing boats and vehicles, cleaning external areas using water and watering gardens. Differences between the two measures included among other aspects, the number of hours and days of the week that gardens could be watered. Under restrictions, sprinklers were banned at all times whereas under PWCM, sprinklers were permitted within restricted hours of operation. The less rigorous PWCM were aimed at long term water efficiency and required 'sensible water use' [40,41]. Breaches of PWCM and restrictions carried the same penalty (a fine of AUD \$345); prior to 2008-2009 it was AUD \$315 [42], although enforcement was lax as it mostly relied on neighbors reporting breaches followed by a water restriction enforcement officer witnessing a subsequent breach on the property.

\subsection{The Price of Water}

A state-wide water pricing policy in South Australia means that all consumers of water provided by the primary water service provider-SA Water - pay the same rate per volume of water consumed regardless of their location. At the time of the study, an increasing-block water pricing structure was in place. In single dwelling residential properties the first block for water use up to $120 \mathrm{~kL}$ was set at AUD $\$ 0.97$ per kL, the second block at AUD \$1.88 per kL for water use between $120 \mathrm{~kL}$ and $520 \mathrm{~kL}$, and the third block charged AUD \$2.36 per kL for use in excess of $520 \mathrm{~kL}$ [11]. Besides the volume-based water charges the water services costs also included sewerage fees that were priced according to property value, and an annually indexed environmental levy (Save the Murray River Fund) that was introduced in mid-2003.

In 2009 the average residential customer consuming around $191 \mathrm{~kL}$ was paying AUD \$46.90 per quarter, plus service fees [43]. To assist low income users, annual service charges decreased in 2009 to AUD \$137.60. In 2009, the government moved to quarterly billing (rather than six monthly billing) as a means of reducing the impact of large accounts on low income families. Besides these strategies, the water service provider together with state aid organizations also offered a range of payment assistance measures for householders experiencing utility stress. These included flexible payment arrangements, financial counseling, provisions for weekly deductions to pay accounts, and concessions for pensioners and other welfare recipients [43]. These measures were independent of a range of water saving rebates 
also available [44]. The measures were put in place mindful of the impending staged price increases over the next four years [11].

\section{Methodology}

\subsection{Data Collection}

Data for this paper were collected via a postal survey conducted between July and October 2009. Initially, surveys were sent to a random sample of 3000 customers drawn from the water service provider (SA Water) database across three study areas: Metro North, Metro East and Regional and included adults who were responsible for paying the water bill, who resided in an individually metered free standing dwelling, had lived at the address for over 12 months and none of the family members were employees of the water service provider. The water service provider sent out the surveys, which were then returned to the university researchers in a de-identified form to ensure confidentiality. In addition, the same respondents returned a signed consent form to the water service provider permitting them to pass their telephone contact details on to a third party - a computer-assisted telephone interviewing (CATI) company who obtained additional data. The water service provider retained the names and addresses of all participants but received no survey data. The researchers only received numerically identified surveys. Data on each householder's water use was also provided to the researchers, allowing for comparison with attitudes, and intentions to conserve water with actual water use. Ethics approval to conduct the investigation was obtained from the researchers' University ethics committee.

Initially 336 completed surveys were obtained, prompting a second mail out to those householders who had not responded to the first survey. This resulted in a further 216 responses making a total of 552 usable postal surveys, although there was some variation across responses to individual questions (as seen in Table 1).

The population of the greater metropolitan Adelaide area is around 1.2 million people and that of all regional areas across South Australia around 90,000 people. The initial 3000 mail-outs targeting the three sub-areas resulted in an $18 \%$ response rate. This is likely to impact on confidence intervals for the parameters presented, however, the figure is comparable with other Australian research on household water-use studies [44,45]. Qualitative comments are also included, but cannot be taken as thematic accounts as not all respondents provided written statements; they are included merely to add flesh to the quantitative data analysis.

\subsection{Survey Content}

The survey comprised 34 structured questions that asked for demographic information and a range of respondents' beliefs as well as behaviors associated with water conservation, consumption, price, and issues of equity. The survey items were adapted from past environmental research, e.g., [1,19,32,46] and 40 telephone interviews with households randomly selected from the study regions ( 27 households in Adelaide and 13 in the regional town). The questions in the scoping interviews were open-ended designed to clarify concept definition and ascertain the degree of individual variance on concepts in our research program (e.g., perceptions of water pricing, conservation behavior, issue saliency, 
behavioral capacity, equity locus (household, environment, future generations), perceptions of water restrictions, and social trust.

The interview schedule comprised 22 questions and responses were digitally recorded and post-coded into categories generated from the data. In these interviews, participants were asked about their conservation behaviors inside and outside their homes, water pricing opinions, the impact of water restrictions, information requirements to save water, evaluations and beliefs about the water corporation, perceptions of how others use water, and demographic characteristics of themselves, their households and their dwellings. The survey instrument was further refined through pilot testing on a small convenience sample of individuals. The survey questions and statements relevant to this paper are listed in a table two. For each survey item, discrete response options were provided in the form of a Likert scale, the range of which was adapted to suit the questions posed. The questions addressing the fairness of the water price and calculation of the bill were assessed through a 7-point Likert scale, ranging from 'completely unfair' (1) to 'completely fair' (7), with a score of 4 indicating a neutral response. Respondents' opinion on whether the price of water should be increased to encourage people to use less waster was examined via three distinct response options: 'yes', 'no', and 'maybe'. The survey questions examining whether increasing the price paid by domestic and non-domestic water users was an acceptable way to conserve water offered respondents seven response options, ranging from 'completely unacceptable' (1) to 'completely acceptable' (7), with 4 denoting neutral responses. All other survey items required respondents to select their response from a 7-point Likert scale assessing agreeability, ranging from 'strongly disagree' (1) to 'strongly agree' (7), again 4 marked neutral responses.

\subsection{Data Preparation and Analysis}

Bivariate logistic regression analyses were performed to examine the relationship between the individual demographic predictors and the survey items. Multivariate binary logistic regression models were specified for predictors showing a significant association with the outcome variable at $p=0.25$ [47]. Following suggestions by Field [48], relevant predictor variables were entered in one block rather than stepwise procedures. Predictor variables that were entered into the multivariate model but returned as not significant were in turn tested against models containing only significant predictor variables. This process allowed for the comparison of several models, yielding a final model for every outcome variable, which included only significant predictor variables. All tests were done using SPSS Version 17.

All outcome variables were dichotomized for analysis. This was necessary given the comparatively low response rate resulting in insufficient cell frequencies for analysis based on all seven response options respondents were provided with. Likert scale responses examining agreeability were combined to yield two levels, namely 'agree' (response options 5 to 7) and 'disagree' (options 1 to 3). Answers on the fairness and acceptability scales were combined in the same fashion, resulting in the distinction between 'fair' and 'unfair', as well as 'acceptable' and 'unacceptable'. For the single item providing response options in the form of 'no', 'yes' and 'maybe', the latter two options were aggregated to form one category, yielding a distinction between 'yes/maybe' versus 'no'. We explored omitting 'maybe' responses instead of combining them with 'yes' responses, however, similar results were obtained. 
Catchment area remained a significant predictor and odds ratios obtained were similar to the ones reported here. However, in comparison to a model in which 'yes' and 'maybe' responses are combined, education did not emerge as significantly predictive of opinions on water price increase when 'maybe' responses are omitted from the outcome variable. Where a response option of 'neither/nor' was provided, dichotomizing variables meant this particular response was excluded from analysis, as it would have been inappropriate to merge this response with either of the two outcome levels (e.g., agree or disagree). 'Neither/nor' responses may have been chosen by respondents who had not made up their mind about the particular issue in question, or who felt that their response was more complex or even needed a different 'label' than the ones provided. Given the ambiguity of 'neither/nor', merging these responses with an overall 'agree' or 'disagree', for instance, would have introduced bias and potentially skewed the results.

\section{Results}

The results section commences with a summary of the characteristics of the survey respondents (Table 1). Given that the aim of the investigation was to determine whether respondents' perceptions of the water price, pricing structure, price increases, equity and the impact of pricing on conservation could be predicted from their socio-economic and demographic characteristics, the subsections that follow are structured according to the various socio-economic and demographic predictor variables, namely: education, employment, location, annual household income, household size and lot size. All predictor variables were entered into the analysis as categorical variables, the individual levels of which and their respective frequencies, are given in Table 2.

For three of the 16 outcome variables, a regression model could not be successfully specified with the predictor variables, i.e. none of the predictors were associated with the outcome variable under investigation despite an adopted significance level of $p<0.25$ at the bivariate level. These included statements on whether charging more for water will hurt large households, whether everyone should pay the same price for the water they use, and if households that use an above average amount of water should pay a higher price (Table 3). It can therefore be concluded that these three pricing issues cannot be predicted by any of the demographic and socio-economic variables included in the analysis. Furthermore, across the successfully specified regression models, respondents' age and the number of children in the household did not emerge as significant predictors, hence it can be said to hold no significant indicative qualities for the water pricing issues examined. Fit indices and parameter estimates for the successfully specified models are reported in Table 2. 
Table 1. Demographic and socio-economic characteristics of survey respondents in the three study areas.

\begin{tabular}{|c|c|c|c|c|c|}
\hline \multirow[b]{2}{*}{ Variable } & \multicolumn{3}{|c|}{ Study area } & \multirow[b]{2}{*}{$\begin{array}{c}\text { Chi-square } \\
(d f)\end{array}$} & \multirow[b]{2}{*}{$p$} \\
\hline & $\begin{array}{c}\text { Metro East } \\
\mathrm{N}(\%) \\
\end{array}$ & $\begin{array}{c}\text { Metro North } \\
\text { n }(\%)\end{array}$ & $\begin{array}{c}\text { Regional } \\
\mathrm{n}(\%)\end{array}$ & & \\
\hline Gender & & & & $0.32(2)$ & 0.85 \\
\hline Male & $128(56.1 \%)$ & $80(53.3 \%)$ & $90(55.9 \%)$ & & \\
\hline Female & $100(43.9 \%)$ & $70(46.7 \%)$ & $71(44.1 \%)$ & & \\
\hline Age & & & & $24.42(10)$ & 0.007 \\
\hline $18-29$ & $0(0)$ & $8(5.3)$ & $8(4.9)$ & & \\
\hline $30-39$ & $15(6.6)$ & $13(8.7)$ & $11(6.8)$ & & \\
\hline $40-49$ & $36(15.9)$ & $32(21.3)$ & $36(22.2)$ & & \\
\hline $50-59$ & $60(26.4)$ & $46(30.7)$ & $50(30.9)$ & & \\
\hline $60-69$ & $69(30.4)$ & $30(20.0)$ & $36(22.2)$ & & \\
\hline $70+$ & $47(20.7)$ & $21(14.0)$ & $21(13.0)$ & & \\
\hline Income (AUD \$) & & & & $73.8(16)$ & $<0.001$ \\
\hline$<\$ 10,400$ & $2(1.0)$ & $5(3.9)$ & $2(1.4)$ & & \\
\hline$\$ 10,400-\$ 20,800$ & $11(5.6)$ & $17(13.3)$ & $17(12.1)$ & & \\
\hline$\$ 20,801-\$ 31,200$ & $15(7.6)$ & $19(14.8)$ & $15(10.7)$ & & \\
\hline$\$ 31,201-\$ 41,600$ & $9(4.5)$ & $14(10.9)$ & $16(11.4)$ & & \\
\hline$\$ 41,601-\$ 52,000$ & $15(7.6)$ & $8(6.3)$ & $9(6.4)$ & & \\
\hline$\$ 52,001-\$ 78,000$ & $30(15.2)$ & $26(20.3)$ & $37(26.4)$ & & \\
\hline$\$ 78,001-\$ 104,000$ & $25(12.6)$ & $23(18.0)$ & $20(14.3)$ & & \\
\hline$\$ 104,001-\$ 156,000$ & $36(18.2)$ & $11(8.6)$ & $16(11.4)$ & & \\
\hline$>\$ 156,000$ & $55(27.8)$ & $5(3.9)$ & $8(5.7)$ & & \\
\hline Education & & & & $89.26(10)$ & $<0.001$ \\
\hline Secondary school & $32(14.2)$ & $55(37.4)$ & $56(35.7)$ & & \\
\hline Incomplete tertiary & $9(4.0)$ & $7(4.8)$ & $10(6.4)$ & & \\
\hline Technical tertiary & $38(16.8)$ & $33(22.4)$ & $37(23.6)$ & & \\
\hline Undergraduate & $62(27.4)$ & $24(16.3)$ & $25(15.9)$ & & \\
\hline Postgraduate & $78(34.5)$ & $13(8.8)$ & $13(8.3)$ & & \\
\hline Other & $7(3.1)$ & $15(10.2)$ & $16(10.2)$ & & \\
\hline Employment $^{\mathrm{i}}$ & & & & $13.33(8)$ & 0.1 \\
\hline Full-time & $86(44.8)$ & $58(42.3)$ & $76(51.0)$ & & \\
\hline Part-time & $45(23.4)$ & $18(13.1)$ & $25(16.8)$ & & \\
\hline Seeking work & $3(1.6)$ & $4(2.9)$ & $5(3.4)$ & & \\
\hline Unemployed & $5(2.6)$ & $4(2.9)$ & $0(0)$ & & \\
\hline Home maker & $11(5.7)$ & $5(3.6)$ & $6(4.0)$ & & \\
\hline Pensioner & $42(21.9)$ & $47(34.3)$ & $35(23.5)$ & & \\
\hline Student & $0(0)$ & $1(0.7)$ & $2(1.3)$ & & \\
\hline
\end{tabular}

Note: ${ }^{i}$ The category Unemployed includes those looking for work, but not those who are no longer looking for work. 
Table 2. Model fit indices and parameter estimates for regression models, organized by outcome variable.

\begin{tabular}{|c|c|c|c|c|c|}
\hline Outcome (Predicted response category) & Predictor (Reference level) & $\begin{array}{c}\text { Model } \chi^{2}(\mathbf{d f}) \\
\text { Nagelkerke } \mathbf{R}^{2}\end{array}$ & $\begin{array}{c}\text { Predictor } \\
\text { Wald } \chi^{2}(\mathbf{d f})\end{array}$ & OR & 95\% CI \\
\hline \multirow{5}{*}{$\begin{array}{l}\text { How fair is the current price of water? } \\
\text { (Fair) }\end{array}$} & & $11.18(2)^{* * \mathrm{i}}$ & & & \\
\hline & & 0.037 & & & \\
\hline & Study area (Metro East) & & $11.00(2)^{* *}$ & & \\
\hline & Metro North & & & $0.44 * *$ & $0.27-0.71$ \\
\hline & Regional & & & 0.67 & $0.41-1.09$ \\
\hline \multirow{5}{*}{$\begin{array}{l}\text { How fair is the current method of } \\
\text { calculating your water bill? } \\
\text { (Fair) }\end{array}$} & & $7.72(2)^{*}$ & & & \\
\hline & & 0.028 & & & \\
\hline & Income $(>\$ 78,000)$ & & $7.59(2)^{*}$ & & \\
\hline & $\$ 31,201-\$ 78,000$ & & & $0.51^{* *}$ & $0.32-0.83$ \\
\hline & $<\$ 31,201$ & & & 0.63 & $0.36-1.11$ \\
\hline \multirow{11}{*}{$\begin{array}{l}\text { Do you think the price of water should be } \\
\text { increased to encourage people to use less? } \\
\text { (Yes/Maybe) }\end{array}$} & & $43.08(7)^{* * *}$ & & & \\
\hline & & 0.106 & & & \\
\hline & Study area (Metro East) & & $9.29(2)^{*}$ & & \\
\hline & Metro North & & & $0.49 * *$ & $0.31-0.79$ \\
\hline & Regional & & & $0.64(*)$ & $0.41-1.01$ \\
\hline & Education (Completed secondary) & & $17.58(5)^{* *}$ & & \\
\hline & Incomplete tertiary & & & 1.56 & $0.64-3.76$ \\
\hline & Technical tertiary & & & 1.50 & $0.87-2.59$ \\
\hline & Undergraduate & & & $2.06 * *$ & $1.19-3.54$ \\
\hline & Postgraduate & & & $3.21 * * *$ & $1.80-5.71$ \\
\hline & Other & & & 1.12 & $0.51-2.50$ \\
\hline \multirow{4}{*}{$\begin{array}{l}\text { The price of water should be higher in } \\
\text { times of drought and lower when water } \\
\text { is plentiful. } \\
\text { (Agree) }\end{array}$} & & $3.71(1)(*)$ & & & \\
\hline & & 0.011 & & & \\
\hline & Gender (Male) & & $3.70(1)(*)$ & & \\
\hline & Female & & & $1.45\left(^{*}\right)$ & $0.99-2.11$ \\
\hline
\end{tabular}


Table 2. Cont

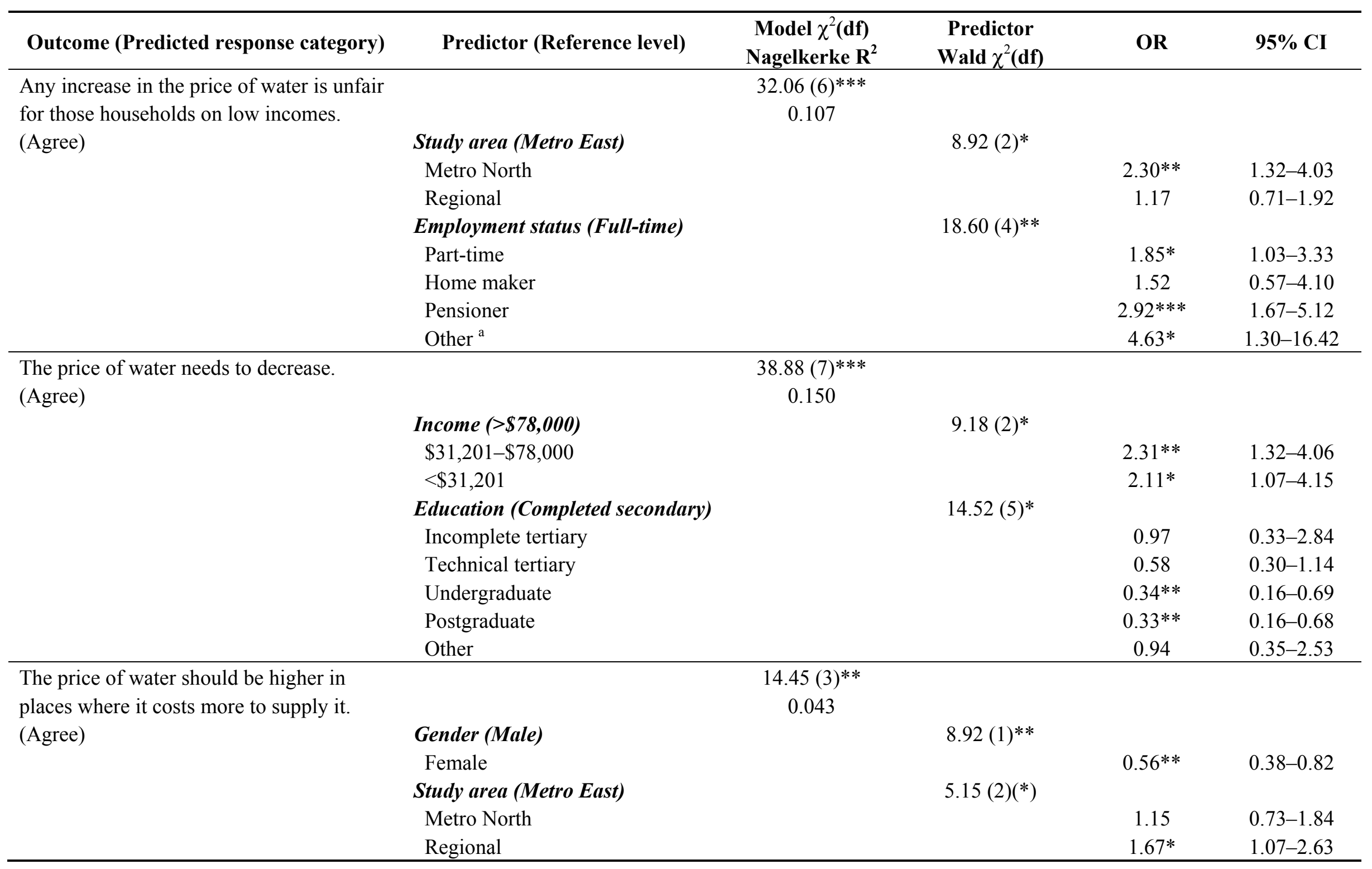


Table 2. Cont.

\begin{tabular}{|c|c|c|c|c|c|}
\hline Outcome (Predicted response category) & Predictor (Reference level) & $\begin{array}{c}\text { Model } \chi^{2}(\mathbf{d f}) \\
\text { Nagelkerke } \mathbf{R}^{2} \\
\end{array}$ & $\begin{array}{c}\text { Predictor } \\
\text { Wald } \chi^{2}(\mathbf{d f})\end{array}$ & $\mathbf{O R}$ & $95 \% \mathrm{CI}$ \\
\hline $\begin{array}{l}\text { Charging more for water will hurt large } \\
\text { households. } \\
\text { (Agree) }\end{array}$ & & ii & & & \\
\hline $\begin{array}{l}\text { Everyone should pay the same price for the } \\
\text { water they use. } \\
\text { (Agree) }\end{array}$ & & ii & & & \\
\hline $\begin{array}{l}\text { Access to a basic amount of water is a } \\
\text { necessity of life and not something }\end{array}$ & & $\begin{array}{c}13.36(4)^{*} \\
0.044\end{array}$ & & & \\
\hline households should have to pay for. & Lot size $(<500)$ & & $6.11(2)^{*}$ & & \\
\hline \multirow[t]{5}{*}{ (Agree) } & $500-900$ & & & $2.01 *$ & $1.07-3.75$ \\
\hline & $>900$ & & & 1.35 & $0.68-2.69$ \\
\hline & Income $(>\$ 78,000)$ & & $5.90(2)(*)$ & & \\
\hline & $\$ 31,201-\$ 78,000$ & & & $1.70 *$ & $1.07-2.69$ \\
\hline & $<\$ 31,201$ & & & 1.62 & $0.92-2.84$ \\
\hline The current price of water is high enough & & $44.64(4)^{* * *}$ & & & \\
\hline to encourage conservation & & 0.146 & & & \\
\hline \multirow[t]{6}{*}{ (Agree) } & Study area (Metro East) & & $9.75(2)^{* *}$ & & \\
\hline & Metro North & & & $2.53 * *$ & $1.40-4.59$ \\
\hline & Regional & & & 1.55 & $0.91-2.65$ \\
\hline & Income in AUD $\$(>\$ 78,000)$ & & $22.11(2)^{* * *}$ & & \\
\hline & $\$ 31,201-\$ 78,000$ & & & $2.92 * * *$ & $1.73-4.91$ \\
\hline & $<\$ 31,201$ & & & $3.24 * * *$ & $1.69-6.21$ \\
\hline
\end{tabular}


Table 2. Cont.

\begin{tabular}{|c|c|c|c|c|c|}
\hline Outcome (Predicted response category) & Predictor (Reference level) & $\begin{array}{c}\text { Model } \chi^{2}(\mathbf{d f}) \\
\text { Nagelkerke } \mathbf{R}^{2}\end{array}$ & $\begin{array}{c}\text { Predictor } \\
\text { Wald } \chi^{2}(\text { df) }\end{array}$ & OR & $95 \% \mathrm{CI}$ \\
\hline Increasing the price of water won't make & & $16.61(6)^{*}$ & & & \\
\hline my household use less. & & 0.049 & & & \\
\hline \multirow[t]{8}{*}{ (Agree) } & Gender (Male) & & $4.53(1)^{*}$ & & \\
\hline & Female & & & $1.54^{*}$ & $1.04-2.28$ \\
\hline & Education (Completed secondary) & & $12.23(5)^{*}$ & & \\
\hline & Incomplete tertiary & & & 0.95 & $0.36-2.49$ \\
\hline & Technical tertiary & & & 0.62 & $0.35-1.11$ \\
\hline & Undergraduate & & & $0.38^{* *}$ & $0.22-0.68$ \\
\hline & Postgraduate & & & 0.64 & $0.36-1.16$ \\
\hline & Other & & & $0.47(*)$ & $0.21-1.09$ \\
\hline $\begin{array}{l}\text { Households that use an amount of water } \\
\text { well above average should have to pay a } \\
\text { higher price for their excess water use. } \\
\text { (Agree) }\end{array}$ & & ii & & & \\
\hline Households that use well below average & & $8.02(2)^{*}$ & & & \\
\hline amounts of water should get a & & 0.024 & & & \\
\hline price discount. & Study area (Metro East) & & $7.69(2)^{*}$ & & \\
\hline \multirow[t]{2}{*}{ (Agree) } & Metro North & & & $2.11^{* *}$ & $1.24-3.60$ \\
\hline & Regional & & & 1.40 & $0.86-2.26$ \\
\hline I believe that stepped tariffs are a good way & & $13.08(4)^{*}$ & & & \\
\hline of charging for water. & & 0.053 & & & \\
\hline \multirow[t]{6}{*}{ (Agree) } & Lot size $(<500)$ & & $5.39(2)(*)$ & & \\
\hline & $500-900$ & & & $0.33^{*}$ & $0.11-0.98$ \\
\hline & $>900$ & & & $0.26^{*}$ & $0.08-0.81$ \\
\hline & Income in AUD $\$(>\$ 78,000)$ & & $6.57(2)^{*}$ & & \\
\hline & $\$ 31,201-\$ 78,000$ & & & $0.47 *$ & $0.27-0.84$ \\
\hline & $<\$ 31,201$ & & & 0.69 & $0.33-1.41$ \\
\hline
\end{tabular}


Table 2. Cont.

\begin{tabular}{|c|c|c|c|c|c|}
\hline Outcome (Predicted response category) & Predictor (Reference level) & $\begin{array}{c}\text { Model } \chi^{2}(\mathbf{d f}) \\
\text { Nagelkerke } \mathbf{R}^{2}\end{array}$ & $\begin{array}{c}\text { Predictor } \\
\text { Wald } \chi^{2}(\mathbf{d f})\end{array}$ & OR & $95 \%$ CI \\
\hline Increasing the price of water paid by & & $72.39(12)^{* * *}$ & & & \\
\hline households as an acceptable way to & & 0.247 & & & \\
\hline conserve water. & Study area (Metro East) & & $15.00(2)^{* *}$ & & \\
\hline \multirow[t]{15}{*}{ (Acceptable) } & Metro North & & & $0.29 * * *$ & $0.16-0.54$ \\
\hline & Regional & & & 0.67 & $0.37-1.19$ \\
\hline & Income $(>\$ 78,000)$ & & $13.14(2)^{* *}$ & & \\
\hline & $\$ 31,201-\$ 78,000$ & & & $0.38 * *$ & $0.20-0.73$ \\
\hline & $<\$ 31,201$ & & & $0.18 * *$ & $0.07-0.48$ \\
\hline & Employment status (Full-time) & & $8.85(4)(*)$ & & \\
\hline & Part-time & & & 1.45 & $0.75-2.79$ \\
\hline & Home maker & & & $4.69 * *$ & $1.52-14.46$ \\
\hline & Pensioner & & & 1.00 & $0.43-2.31$ \\
\hline & Other & & & 0.74 & $0.20-2.69$ \\
\hline & Household size (Five or more) & & $15.60(4)^{* *}$ & & \\
\hline & Four people & & & $2.72 *$ & $1.02-7.29$ \\
\hline & Three people & & & 1.64 & $0.58-4.64$ \\
\hline & Two people & & & $4.45^{* *}$ & $1.74-11.40$ \\
\hline & Single person household & & & $5.57 * *$ & $1.81-17.09$ \\
\hline Increasing the price of water paid by & & $14.80(5)^{*}$ & & & \\
\hline non-domestic users is an acceptable way to & & 0.051 & & & \\
\hline conserve water. & Education (Completed secondary) & & $13.79(5)^{*}$ & & \\
\hline \multirow[t]{5}{*}{ (Acceptable) } & Incomplete tertiary & & & 1.47 & $0.50-4.28$ \\
\hline & Technical tertiary & & & 1.19 & $0.64-2.20$ \\
\hline & Undergraduate & & & $2.30 *$ & $1.14-4.62$ \\
\hline & Postgraduate & & & $3.04 * *$ & $1.44-6.42$ \\
\hline & Other & & & $3.53(*)$ & $1.00-12.47$ \\
\hline
\end{tabular}

Notes: ${ }^{\mathrm{i} *} p<0.05,{ }^{* *} p<0.01, * * * p<0.001,\left({ }^{*}\right) p<0.07$ (marginally significant); ${ }^{\text {ii }}$ No association between predictor variables and outcome variables; ${ }^{\mathrm{a}}$ The category Other includes the unemployed, and those not looking for work, but not on any form of welfare payment. 
Table 3. Summary of the predictor variables for the fairness of water pricing, price increases and pricing as a driver of conservation.

\begin{tabular}{|c|c|c|}
\hline Question Cluster $^{\mathrm{i}}$ & Particular survey items & Significant predictors \\
\hline The fairness of water pricing & $\begin{array}{l}\text { - How fair is the current price of water (each tariff step and not the } \\
\text { service charges)? } \\
\text { - How fair is the current method of calculating your water bill (using } \\
\text { stepped tariffs)? } \\
\text { - I believe that stepped tariffs are a good way of charging for water. } \\
\text { - Access to a basic amount of water is a necessity of life and not something } \\
\text { - households should have to pay for. } \\
\text { - } \text { Everyone should pay the same price for the water they use. }\end{array}$ & $\begin{array}{l}\text { - Location } \\
\text { - Income } \\
\text { - Income, lot size } \\
\text { - Income, lot size } \\
\text { - - } \\
\text { - Income, education }\end{array}$ \\
\hline Water price increases & $\begin{array}{l}\text { - Any increase in the price of water is unfair for those households on } \\
\text { low incomes. } \\
\text { - Charging more for water will hurt large households. } \\
\text { - The price of water should be higher in places where it costs more to supply it. }\end{array}$ & $\begin{array}{l}\text { - Location, employment } \\
\text { - - } \\
\text { - Location, gender }\end{array}$ \\
\hline $\begin{array}{l}\text { Water pricing as a driver of } \\
\text { Conservation }\end{array}$ & $\begin{array}{l}\text { - Do you think the price of water should be increased to encourage people to } \\
\text { use less? } \\
\text { - The price of water should be higher in times of drought and lower when water } \\
\text { is plentiful. } \\
\text { - The current price of water is high enough to encourage conservation. } \\
\text { - Increasing the price of water won't make my household use less. } \\
\text { - Households that use an amount of water well above average should have to pay } \\
\text { - Households that use well below average amounts of water should get a } \\
\text { - } \text { - Increasing the price of water paid by households is an acceptable way to } \\
\text { conserve water. }\end{array}$ & $\begin{array}{l}\text { - Location, education } \\
\text { - Gender } \\
\text { - Location, income } \\
\text { - Gender, education } \\
\text { - }- \\
\text { - Location } \\
\text { - Location, income, } \\
\text { employment, household size }\end{array}$ \\
\hline
\end{tabular}

Note: ${ }^{i}$ The term cluster was chosen to denote a set of survey items which address a similar issue. This should not be confused with the term cluster as used within the context of cluster analysis. 


\subsection{Characteristics of Survey Respondents}

The postal survey asked respondents to provide data on income, education, gender, age and block or lot size, number of years resident, number of days occupied and number of residents per household. Table 1 provides a summary of respondents' demographic and socio-economic characteristics in the three areas under investigation. More males than females responded to the survey across all three areas.

The majority of survey respondents were over 50 years old, with the highest concentration in the 50-59 year age bracket. There was some variation across the three areas with slightly more 40-49 year olds from Metro North and Regional participating, than Metro East. The response rate for the 18-24 and 25-29 year olds was negligible, and low for the 30-39 years bracket. For analytical purposes, cell frequencies were collapsed across the two youngest age groups (18-24 and 25-29) to form one category, resulting in an improved distribution of younger respondents across the three areas. Chi-square analysis indicated age differences between the three study areas to be significant, driven in particular by lower than expected cell frequencies of individuals between 18 and 29 in the Metro East region $(\mathrm{z}=-2.6)$.

A greater proportion of respondents from Metro East (27.8\%) had incomes above AUD \$156,000 compared to $3.9 \%$ in Metro North and $5.7 \%$ in Regional. Statistically significant differences in household income between the three areas were observed. This was due to higher than expected cell counts for an annual household income greater than AUD \$156,000 in the Metro East area $(z=4.9)$. In contrast, observed frequencies of households with an income of more than AUD \$156,000 were significantly lower in Metro North $(z=-3.2)$ and Regional $(z=-2.7)$. These findings support the notion of economic differences between the three areas under investigation.

Education levels for the three areas were consistent with the data on income. Approximately 34.5\% of respondents in Metro East had completed a postgraduate qualification compared with $8.8 \%$ in Metro North and $8.3 \%$ in Regional. The Social Health Atlas of South Australia records a strong correlation between education, income, and type of employment with higher percentages of professionals residing in high income suburbs [49]. Inferential statistics returned these differences as statistically significant. Residents in the Metro North and Regional were more likely to have only completed secondary education $(z=2.4$ and 2.1, respectively) than Metro East $(z=3.7)$, while Metro East respondents were more likely to have completed an undergraduate $(\mathrm{z}=2.1)$ or postgraduate degree $(\mathrm{z}=5.1)$, and less likely to have completed some other form of qualification $(z=-2.3)$. Metro North and Regional respondents were less likely to have completed a postgraduate degree $(\mathrm{z}=-3.0$ and $\mathrm{z}=-3.2$, respectively). The majority of respondents were employed either full- or part-time across all three areas (68.2\% East, 55.4\% North, 67.8\% Regional). Metro North had the highest percentage of pensioners at $34.3 \%$, although not the highest percentage of respondents over the age of 60 . Women at home engaged in full-time home duties (5.7\% East, 3.6\% North, 4.0\% Regional) had a low response rate to the survey, as did the unemployed. The categories of 'unemployed', 'seeking work' and 'student' were combined to obtain viable cell frequencies for analysis; there were no significant differences between study areas in regards to respondents' employment status. While the Australian Bureau of Statistics classifies individuals who are unemployed, but not registered as seeking work as 
not seeking work, the survey did not make this distinction. Hence in classifying the unemployed respondents it is not clear whether they were seeking work or not [39].

\subsection{Education}

Higher levels of educational attainment were associated with being more likely to think that an increase in price would encourage people (the public) to conserve water, and that increasing the price to non-domestic water users such as industry and mining was an acceptable means of driving water conservation. Specifically, having completed an undergraduate or postgraduate degree rather than a secondary qualification increased the likelihood of respondents stating 'yes' or 'maybe' by a factor of $2(\mathrm{OR}=2.06, p<0.01)$ and $3.2(\mathrm{OR}=3.21, p<0.001)$ respectively in response to questions asking whether increasing the price of water price would encourage people to conserve water (Table 2). Householders who had completed an undergraduate degree were $130 \%$ more likely to state that increasing the price of water paid by non-domestic water users was an acceptable way to conserve water $(\mathrm{OR}=2.3, p<0.05)$ than those who only had secondary educational qualifications, while those with a postgraduate degree were more than three times as likely to say so $(\mathrm{OR}=3.04, p<0.01)$, than those limited to a secondary education. Respondents with an educational attainment classified as 'other' were also observed to be more likely to think that increasing the price of water was an acceptable approach to conservation. However, this result was only marginally significant $(\mathrm{OR}=3.53$, $p<0.06)$.

In contrast to the results for the previous two items, householders with higher levels of educational attainment were less likely to believe the price of water should be reduced, or that any increase in the price of water would reduce consumption. When asked whether the current price of water needed to decrease, respondents with an undergraduate or postgraduate degree were $70 \%$ less likely to agree with the statement than individuals who had only completed a secondary qualification $(\mathrm{OR}=0.34, p<0.01$, and $\mathrm{OR}=0.33, p<0.01$, respectively). Furthermore, those with an undergraduate degree were less likely than their counterparts with a secondary education $(\mathrm{OR}=0.38, p<0.01)$ to state that an increase in price would result in lower water consumption.

\subsection{Employment}

Respondents' employment was significant for whether a price increase was considered unfair on low income households and whether increasing the price of water was an acceptable way to drive water conservation. Relative to respondents in full-time employment, individuals in part-time employment were approximately $90 \%$ more likely to think increases were unfair on low income households $(\mathrm{OR}=1.85, p<0.05)$, while being a pensioner or belonging to the category including students, unemployed and seeking work increased the likelihood of agreeing with this statement by a factor of $3(\mathrm{OR}=2.92, p<0.001)$ and $4.6(\mathrm{OR}=4.63, p<0.05)$, respectively (Table 2). For the statement addressing the acceptability of price increases for households, respondents who indicated that they were a 'home maker' were over four and a half times more likely to think price increases acceptable than those in full-time employment $(\mathrm{OR}=4.69, p<0.01)$, with no other levels contributing to the significance of employment status as a predictor for the outcome variables in question. 


\subsection{Location}

The variable which emerged as being the most significant in predicting attitudes towards water pricing was location, for it held predictive qualities for seven of the pricing issues assessed (Table 3). Relative to respondents residing in the Metro East area, Metro North respondents were 55\% less likely to consider the current water price as fair $(\mathrm{OR}=0.44, p<0.01)$, and $70 \%$ less likely to consider a domestic water price increase an acceptable way to conserve water (OR $=0.29, p<0.001)$. Furthermore, Metro North respondents, and marginally so Regional residents, were less likely than their Metro East counterparts to believe that the current price of water should be increased to encourage conservation, the former showing a $50 \%$ decrease $(\mathrm{OR}=0.49, p<0.01)$ and the latter a $35 \%$ decrease $(\mathrm{OR}=0.64, p<0.06)$ in their likelihood of responding 'yes' or 'maybe'.

Opposite patterns emerged for survey items assessing whether respondents considered a price increase unfair on low income households, the current price high enough to encourage conservation, and whether a discount should apply to those using well below average amounts of water-for all these variables Metro North respondents were more likely to answer affirmatively than Metro East residents. Moreover, Regional residents were also found to be more likely than those residing in Metro East to think that the price of water should be higher in places where it costs more to supply it. Specifically, using Metro East householders as the reference group, Metro North respondents were $130 \%$ more likely to agree that price increases were unfair on low income households $(\mathrm{OR}=2.3$, $p<0.01$ ), two and a half times more likely to believe that the current price of water was high enough to encourage conservation $(\mathrm{OR}=2.53, p<0.01)$ and more than twice as likely to think that a discount should apply for households which have below average water use ( $\mathrm{OR}=2.11, p<0.01)$. Regional householders were found to be almost $70 \%$ more likely than Metro East respondents $(\mathrm{OR}=1.67$, $p<0.05)$ to agree with the statement that water should cost more in places where it costs the water service provider more to supply the water.

\subsection{Annual Household Income}

The demographic data demonstrate differences between the three study areas based on socio-economic status. Respondents in Metro North and Regional had significantly lower incomes than Metro East, although the data on income indicate that slightly more householders in Regional had incomes over AUD \$52,001 (58\%) compared to Metro North (50\%). Consistent with income, educational levels also differed across the three areas.

Levels of annual household income were found to be predictive of a range of water pricing survey items. Lower levels of household income were associated with an increased likelihood of stating that the price of water needs to decrease, that access to a basic amount of water is a necessity rather than something that should be paid for, as well as the current water price was high enough to encourage conservation. Compared to the highest income earners (>AUD \$78,000), respondents with an income of between AUD \$31,201 and AUD \$78,000 and those in the lowest income bracket (< AUD \$31,201) were found to be more than twice as likely to agree that the current price of water needs to decrease $(\mathrm{OR}=2.31, p<0.01$, and $\mathrm{OR}=2.11, p<0.05$, respectively), and around three times as likely to believe that the current price of water was high enough to encourage conservation $(\mathrm{OR}=2.92$, 
$p<0.001$, and $\mathrm{OR}=3.24, p<0.001$, respectively). Householders with between AUD $\$ 31,201$ and AUD $\$ 78,000$ at their disposal were also observed to be more than $70 \%$ more likely to think that access to a basic amount of water was a necessity rather than a commodity to be purchased $(\mathrm{OR}=1.7$, $p<0.05)$.

Individuals with lower levels of household income were less likely than their higher earning counterparts to consider the current method of calculating the water bill fair, to think that stepped tariffs were a good way to charge for water and that increasing the price of water paid by households was an acceptable way of driving conservation of the resource. Compared with householders in the highest annual household income bracket, respondents with an income of between AUD \$31,201 and AUD $\$ 78,000$ were $50 \%$ less likely to think that the current method for calculating the water bill was fair $(\mathrm{OR}=0.51, p<0.01)$ and that stepped tariffs were a good way of charging for water $(\mathrm{OR}=0.47$, $p<0.05)$. Furthermore, householders with between AUD \$31,201 and AUD \$78,000 were approximately $60 \%$ less likely to regard an increase in the price of water paid by households acceptable to conserve water $(\mathrm{OR}=0.38, p<0.01)$, while those in the lowest annual household income bracket (i.e., less than AUD \$31,201) were more than 80\% less likely than those with the highest income level $(\mathrm{OR}=0.18, p<0.01)$.

\subsection{Household Size (Number of Occupants)}

Respondents living in households with fewer occupants were more likely to consider price increases an acceptable way to conserve water than those living in larger households. In comparison to individuals living in households comprising five or more individuals, respondents from households including four people were $170 \%$ more likely $(\mathrm{OR}=2.72, p<0.05)$ to find price increases for households acceptable, while individuals living with one other person or those living alone were four and a half times $(\mathrm{OR}=4.45, p<0.01)$ and more than five and a half times $(\mathrm{OR}=5.57, p<0.01)$ respectively, more likely to think this acceptable.

\subsection{Lot Size}

Having a larger lot (property) size was associated with being more likely to think that access to a basic amount of water was a necessity and not something one should have to pay for, and associated with being less likely to think that stepped tariffs were a good way of charging for water. Specifically, householders with a lot size of between $500 \mathrm{~m}^{2}$ and $900 \mathrm{~m}^{2}$ were twice as likely to agree with the statement regarding access to a water allowance as a necessity compared to individuals whose lot size was less than $500 \mathrm{~m}^{2}(\mathrm{OR}=2.01, p<0.05)$. In contrast, respondents with lot sizes of between $500 \mathrm{~m}^{2}$ and $900 \mathrm{~m}^{2}$, and more than $900 \mathrm{~m}^{2}$ were approximately $80 \%$ less likely to agree with stepped tariffs as a good way of charging for water $(\mathrm{OR}=0.33, p<0.05$, and $\mathrm{OR}=0.26, p<0.05$, respectively).

\subsection{Qualitative Results}

The surveys provided respondents with an opportunity to comment further on any matters raised in the questionnaire, or related matters. It is not possible to do statistical analyses on the qualitative data, however, the three quotes below are typical of the more than forty received. They highlight the strong 
feelings of dissatisfaction that some respondents displayed towards the service provider. This was specifically to do with the additional service charges (levies) that formed part of their water invoice or with the manner in which the levies were formulated (Table 4). Some respondents claimed to have reduced their consumption but not to have reaped the economic benefits of reduced costs due to the recently introduced environmental levy; this had left the householders cynical about the monetary value of their water conservation efforts. There were distinct location-based differences in opinions with Regional residents objecting to paying the environmental levy (Save the Murray River Fund) when they did not rely on that source of water. Those from the more affluent Metro East objected to the link between sewerage charges and property value.

Table 4. Selected comments from survey respondents objecting to various aspects of the water charges.

\begin{tabular}{|c|c|}
\hline Origin of respondent & Comment \\
\hline Regional & $\begin{array}{l}\text { "You didn't ask how we feel about paying the Murray River Water Levy when } \\
\text { we live } 400 \mathrm{~km} \text { away from the river and don't access its water." }\end{array}$ \\
\hline Metro East & $\begin{array}{l}\text { "I am unsure of the charges made by SA Water but I think if there is a difference } \\
\text { in charges according to the suburb that one lives in I think that that is unfair. I } \\
\text { have always tried to be water efficient no matter where I lived and maybe it is } \\
\text { people who have more education and live in more expensive suburbs who use } \\
\text { less-they shouldn't have to pay a premium." }\end{array}$ \\
\hline Metro East & $\begin{array}{l}\text { "Maybe increase the water price by } 50 \% \text { but only the portion in excess of } 520 \mathrm{~kL} \text {. } \\
\text { I believe the tiered price structure is good, although the cost of water is far too } \\
\text { cheap for those who use in excess of } 520 \mathrm{~kL} \text {. Also the service fee based on the } \\
\text { value of the property is ridiculous and cannot be justified." }\end{array}$ \\
\hline
\end{tabular}

The sentiments around the fairness of the environmental water levy are in keeping with those expressed in $\mathrm{Wu}$ et al. [50], in which respondents felt that an environmental water levy should be based on the volume of water consumed and not on their property value. Similarly, the findings of Grafton and Ward [6] advocate for higher prices around the volume of water consumed and a lowering of water service fees.

\section{Discussion}

Some key findings arising from the data analysis warrant further discussion. Firstly, the link between perceptions around the fairness of water pricing and the income of respondents (Table 2); and the stronger feelings among Regional respondents that the price of water should be higher in places where it costs more to supply it, point to common misconceptions around the value of the pricing structure to lower income households.

It costs the water service provider more to supply regional towns with potable water than consumers in the metropolitan areas, but due to the state-wide water pricing policy in South Australia all consumers pay the same rate per volume of water consumed. It is thus ironic that it was predominantly the Regional respondents who were of the opinion that the price of water should be higher in places where it costs more to supply it, when, in effect the metropolitan consumers are subsidizing water prices in regional areas. The results reveal a lack of knowledge around water pricing but at the same 
time an awareness of the environmental levy (itemized on the water bill). Presumably, their opinions were based on a view that the Murray River levy was unfair, and yet they received a subsidy for their own water supply.

Similarly, low income earners were less in favor of the block pricing system than higher income earners, when essentially it can be a means of subsidizing poorer households. It is however likely that a higher percentage of their income was allocated to paying for essential services such as water [26], than their higher earning counterparts. It is possible that people do not have a benchmark for judging water pricing, or that they are not attuned to their quarterly account. Nonetheless, their misconception around the potential cross-subsidization role of the increasing-block pricing system raises an additional issue around consumer awareness.

Thirdly, our results show that larger households were less likely to approve of pricing increases as a means of driving water conservation and respondents with larger lot sizes were less approving of the block pricing system. The aversion to these price increases may be related to residents' awareness of the greater number of occupants, and water-using outlets associated with their larger homes and gardens. In our study, the larger plot sizes may be equated with larger water-hungry gardens though this is not necessarily the case.

Our study showed that some people had installed water saving technologies but had not reaped any financial benefits. This included rainwater tanks, bore water, and dual flush toilets. The value of these water saving devices was off-set by the increases in water use because of the drought and the desire to maintain gardens. The devices allowed for legal use of water, but not necessarily less use. Likewise, Barrett [1] noted that retrofitting water conservation technologies is not always cost effective; nor does it necessarily lead to proportional water savings as behavioral changes may offset any technology-related water savings [2,51]. While occupants of large homes and gardens have the greatest capacity to consume water, they likewise have the greatest capacity to conserve water [52], however, a lack of motivation to use less water or water-related lifestyle interests (such as gardening) may prevent this from happening - this may account for some of the aversion to price increases among the householders with larger properties in our study and links to the concept of social flows [12].

\section{Conclusions: Water Pricing and Social Justice; Conservation versus Cost Recovery}

This paper examines the perceptions of urban and regional water consumers in three areas of South Australia on the fairness of the water pricing system, the impact of increases in water pricing on households and pricing as a driver of water conservation. The study highlighted the concept of social flow; specifically for householders engaged in enhancing their living environment and social activities through ordinary gardening activities. In these examples increases in water costs, or reduction in water use has a detrimental social impact, although there maybe a positive environmental outcome. As Alston and Mason argue [12] the point to make here is that water has a social value, as well as an economic and environmental one and that bringing the social back in is difficult. The social is often championed by marginal groups, such as pensioners, or woman interested in the way water might create community through being a focal point for coming together. In such cases the impact of increasing the price of water, or reducing consumption can fall unevenly on lower income groups who 
may spend a larger percentage of their income on particular activities and in the long term may negatively impact on a community's social capital.

It is also true that the reasons for the price increases may not necessarily be driven by a need to lower consumption, although that is often the publics' assumption during times of price increase. A problem arises in that if prices remain fixed, but consumption drops the water utility loses revenue [2]. Increasing-block water pricing designed to support low income households can also result in a loss of revenue to water utilities [26], which in the long term reduces its capacity to provide and extend its services. Hence, increasing the price of water may be less about conservation than it is about the principle of full cost recovery. The key reasons for water price increases may not be known to consumers and it begs the question: if the reasons behind water price increases were known to consumers would this knowledge lead to greater acceptance of the price increases or the increasing-block pricing structure? This is worthy of further investigation.

The results did not show a general aversion to all aspects of price increases but rather different sectors of the population were particularly resistant to different, specific aspects of water pricing. This result highlights one of the difficulties in large scale surveys where participants are assumed to have knowledge of government policy. Many citizens do not necessarily fully understand the policy details and this is certainly the case in this study. It is not clear whether the differences in views on price increases that characterized the different population groups were a result of ignorance of the pricing structures in place, or a genuine rejection of the policy. The comments listed in Table 4 would suggest ignorance of the way the pricing structure subsidizes the cost to rural householders so that they receive it at the same rate as their urban counterparts.

A further limitation to the study is the comparatively low response rate. This has implications for the extent to which the current results can be generalized, and may have reduced power to find effects in the insignificant models. In regards to the former, the extent to which householders who responded to the survey are representative of the general population or householders in the regions targeted was not directly assessed in this study, hence results pertain only to respondents contained in the sample. Further investigation is required to ascertain how well the current results replicate in a larger sample and to what extent the findings hold up against the populations of interest. In regards to the latter issue, the low response rate may have reduced statistical power to detect and effect, thus replication with a larger sample may detect effects of predictors, which did not yield significant results in this analysis.

In closing, our findings have highlighted public aversion to aspects of water pricing structures and mechanisms and in so doing, afford some insight into how the situation can be redressed. Campaigns aimed at clarifying public misconceptions and delivering appropriate water pricing information to consumers have been shown to reap benefits in terms of improved water conservation behaviors [53-55]. If water price increases are not primarily aimed at driving conservation, but rather about cost-recovery it is also necessary that misconceptions are cleared and consumers are made aware of the real costs associated with ensuring a sustainable, safe and reliable water supply to a growing population facing an uncertain climatic future. 


\section{Acknowledgments}

The research was funded by the Australian Research Council and SA Water. Carmel McCarthy and Pawel Skuza are acknowledged for their assistance with the statistics.

\section{References}

1. Barrett, G. Water conservation: The role of price and regulation in residential water consumption. Econ. Pap. 2004, 23, 271-285.

2. Olmsead, S.; Stavins, R. Comparing Price and Non-Price Approaches to Urban Water Conservation. Available online: http://www.feem.it/userfiles/attach/Publication/NDL2008/ NDL2008-066.pdf (accessed on 12 June 2011).

3. Aisbett, E; Steinhauser, R. Maintaining the Common Pool: Voluntary Water Conservation in Response to Increasing Scarcity; Crawford School Research Paper No. 11; Crawford School of Economics and Government, Australian National University: Canberra, Australia, 2011. Available online: http://papers.ssrn.com/sol3/papers.cfm?abstract_id=1934049 (accessed on 26 January 2013).

4. Allon, F.; Sofoulis, Z. Everyday water: Cultures in transition. Australian Geogr. 2006, 37, 45-55.

5. Chong, J.; Herriman, J.; White, S.; Campbell, D. Review of Water Restrictions: Volume 1: Review and Analysis; Institute for Sustainable Futures, University of Technology Sydney; ACIL Tasman Pty Ltd.: Sydney, Australia, 2009; pp. 17-48.

6. Grafton, R.Q.; Ward, M.B. Prices versus rationing: Marshallian surplus and mandatory water restrictions. Econ. Rec. 2008, 84, S57-S65.

7. Martínez-Espiñeira, R.; Nauges, C. Is all domestic water consumption sensitive to price control? Appl. Econ. 2004, 36, 1697-1703.

8. Pumphrey, R.G.; Edwards, J.A.; Becker, K.G. Urban and rural attitudes toward municipal water controls: A study of a semi-arid region with limited water supplies. Ecol. Econ. 2008, 65, 1-12.

9. Ward, F.A. Cost-benefit and water resources policy: A survey. Water Policy 2011, 14, 250-280.

10. Organisation for Economic Co-operation and Development (OECD). Managing Water for All: An OECD Perspective on Pricing and Financing: Key Messages for Policy Makers; OECD: Paris, France, 2009.

11. South Australian Government. Transparency Statement: Part A Water and Wastewater Prices in Metropolitan and Regional South Australia 2009-2010; SA Government: Adelaide, Australia, 2009.

12. Alston, M.; Mason, R. Who turns the taps off? Introducing social flow to the Australian water debate. Rural Soc. 2008, 18, 131-140.

13. Lockie, S.; Rockloff, S. Decision Frameworks: Assessment of the Social Aspects of Decision Frameworks and Development of a Conceptual Model; Cooperative Research Centre for Coastal Zone, Estuary and Waterway Management Technical Report 20; Central Queensland University: Queensland, Australia, 2005.

14. Nancarrow, B.; Syme, G. Challenges in implementing justice research in the allocation of natural resources. Soc. Justice Res. 2001, 14, 441-452. 
15. Syme, G.J.; Nancarrow, B.E.; McCreddin, J.A. Defining the components of fairness in the allocation of water to environmental and human uses. J. Environ. Manag. 1999, 57, 51-70.

16. Kanakoudis, V.; Tsitsifli, S.; Papadopoulou, A. Integrating the carbon and water footprints' costs in the Water Framework Directive 2000/60/EC Full Water Cost Recovery concept: Basic principles towards their reliable calculation and socially just allocation. Water 2012, 4, 45-62.

17. Rogers, P.; de Silva, R.; Bhatia, R. Water is an economic good: How to use prices to promote equity, efficiency, and sustainability. Water Policy 2002, 4, 1-7.

18. Brennan, D.; Tapsuwan, S.; Ingram, G. The welfare costs of urban outdoor water restrictions. Australian J. Agr. Resour. Econ. 2007, 51, 243-261.

19. Syme, G.J.; Shao, Q.; Po, M.; Campbell, E. Predicting and understanding home garden water use. Landsc. Urban Plan. 2004, 68, 121-128.

20. Moy, C. Rainwater tank households: Water savers or water users? Geogr. Res. 2012, 50, 204-216.

21. Lawrence, J. Electricity: It's Just Essential; SA Council of Social Services and the Office of the Ageing (SA), Office of the Independent Industry Regulator: Adelaide, Australia, 2002.

22. Loh, M.; Coghlan, P. Domestic Water Use Study: In Perth, Western Australia 1998-2001; Water Corporation: Perth, Australia, 2003.

23. Inman, D.; Jeffrey, P. A review of residential demand-side management tool performance and influences on implementation effectiveness. Urban Water J. 2006, 3, 127-143.

24. Pearce, M.; Willis, E.; McCarthy, C.; Ryan, F.; Wadham, B. A Response to the National Water Initiative from Nepabunna, Yarilena, Scotdesco and Davenport Aboriginal Settlements, Report No 36; Desert Knowledge Cooperative Research Centre: Alice Springs, Australia, 2008.

25. McDonald, D.A. The Bell Tolls for Thee: Cost Recovery, Cutoffs, and the Affordability of Municipal Services in South Africa; Municipal Services Project; HSRC Press: Cape Town, South Africa; Zed Books: London, UK, 2001.

26. Ruijs, A. Welfare and distribution effects of water pricing policies. Environ. Resour. Econ. 2009, 43, 161-182.

27. Barberán, R.; Arbués, F. Equity in domestic water rates design. Water Resour. Manag. 2009, 23, 2101-2118.

28. Organisation for Economic Co-operation and Development (OECD). The Price of Water: Trends in OECD Countries; OECD: Paris, France, 2000. Available online: http://www.oecd.org/env/resources/1934075.pdf (accessed on 14 August 2012).

29. Zachariadis, T. Residential water scarcity in Cyprus: Impact of climate change and policy options. Water 2010, 2, 788-814.

30. Duke, J.M.; Ehemann, R. An application of water scarcity pricing with varying threshold, elasticity, and deficit. J. Soil Water Conserv. 2004, 59, 59-65.

31. Official Journal of the European Communities. Directive 2000/60/EC of the European Parliament and of the Council of 23 October 2000 Establishing a Framework for Community Action in the Field of Water Policy; Official Journal of the European Communities: Luxembourge, 2000; pp. L327:1-L327:72. Available online: http://faolex.fao.org/docs/pdf/eur62327.pdf (accessed on 27 January 2013). 
32. Troy, P.; Randolph, B. Water Consumption and the Built Environment: A Social and Behavioral Analysis; NSW Environmental Trust and CRES, Cities Future Research Centre: Sydney, Australia, 2006.

33. Barrett, G.; Wallace, M. Characteristics of Australian urban residential water users: Implications for water demand management and whole of the system water accounting framework. Water Policy 2009, 11, 413-426.

34. Everett, B.; Kemp, A.; Napper, K. Residential Water Use in Sydney, the Blue Mountains and Ilawarra; Research Paper RP26; Independent Pricing and Regulatory Tribunal of New South Wales: Sydney, Australia, 2004. Available online: http://www.ipart.nsw.gov.au/files/RP26.pdf (accessed on 5 May 2011).

35. Harlan, S.L.; Yabiku, S.T.; Larsen, L.; Brazel, A.J. Household water consumption in an arid city: Affluence, affordance and attitudes. Soc. Nat. Resour. 2009, 22, 691-709.

36. Kenney, D.S.; Klein, R.A.; Clark, M.P. Use and effectiveness of municipal water restrictions during drought in Colorado. J. Am. Water Resour. Assoc. 2008, 40, 77-87.

37. Domene, E.; Sauri, D.; Pares, M. Urbanization and sustainable resource use: the case of garden watering in the metropolitan region of Barcelona. Urban Geogr. 2005, 26, 520-535.

38. Willis, R.; Steward, R.; Panuwatwanich, K.; Capati, B.; Giurco, D. Gold Coast domestic water end use study. Water J. Australian Water Assoc. 2009, 84-90.

39. Australian Bureau of Statistics (ABS). Socio-Economic Index of Areas (SEIFA) 2006; ABS: Canberra, Australia, 2008.

40. SA Water. South Australian Water Corporation Annual Report for the Year Ending 30 June 2009; SA Water: Adelaide, Australia 2009. Available online: http://www.sawater.com.au/SAWater/ WhatsNew/Publications/Annual+Reports.htm (accessed on 11 August 2010).

41. SA Water. Permanent Water Conservation Measures; SA Water: Adelaide, Australia, 2009. Available online: http://www.sawater.com.au/SAWater/Environment/WaterRestrictions ConservationMeasures/ (accessed on 4 February 2013).

42. SA Water. Water Restrictions; SA Water: Adelaide, Australia, 2009. Available online: http://www.sawater.com.au/SAWater/Environment/WaterRestrictionsConservationMeasures/ (accessed 4 February 2013).

43. SA Water. New Water Prices for 2009-2010; SA Water: Adelaide, Australia, Available online: http://www.sawater.com.au/sawater/AboutUs/ssxsearch.htm?keywords=water+pricing+2009 (accessed on 11 May 2012).

44. SA Water. Home Rebates; SA Water: Adelaide, Australia, Available online: http://www.sawater.com.au/sawater/yourhome/savewaterinyourhome/rebates_faq.htm (accessed on 11 May 2012).

45. Walton, A.; Hume, M. Creating positive habits in water conservation: The case of the Queensland Water Commission and the target 140 campaign. Int. J. Nonprofit Volunt. Sect. Mark. 2011, 16, 215-224.

46. Newton, P.; Meyer, D. The determinants of urban resource consumption. Environ. Behav. 2012, $44,107-134$.

47. Hosmer, D.W.; Lemeshow, S. Applied Logistic Regression, 2nd ed.; John Wiley and Sons: New York, USA, 2000. 
48. Field, A. Discovering Statistics Using SPSS, 3rd ed.; Sage Publications: London, UK, 2009.

49. Public Health Information Development Unit (PHIDU). Social Health Atlas for South Australia, 2010. Available online: http://www.publichealth.gov.au/interactive-mapping/a-social-health-atlasof-australia_2010.html (accessed on 12 June 2011).

50. Wu, Z.; McKay, J.; Hemphill, E. Roles of levies for sustainable domestic water consumption. Water Resour. Manag. 2011, 25, 929-940.

51. Campbell, H.E.; Johnson, R.M.; Larson, H.E. Prices, devices, people, or rules: The relative effectiveness of policy instruments in water conservation. Rev. Policy Res. 2004, 21, 637-662.

52. De Oliver, M. Attitudes and inaction: a case study of the manifest demographics of urban water conservation. Environ. Behav. 1999, 31, 372-394.

53. Arbués, F.; Barberán, R.; Villanua, I. Price impact on urban residential water demand: A dynamic panel data approach. Water Resour. Res. 2004, 40, W11402.

54. Dahan, M.; Nisan, U. Explaining non-take-up of water subsidy. Water 2011, 3, 1174-1196.

55. Gaudin, S. Effect of price information on residential water demand. Appl. Econ. 2006, 38, 383-393.

(C) 2013 by the authors; licensee MDPI, Basel, Switzerland. This article is an open access article distributed under the terms and conditions of the Creative Commons Attribution license (http://creativecommons.org/licenses/by/3.0/). 